\title{
ENDOSPERM STEROL PHENOTYPE AND GERMINATION IN WHEAT
}

\author{
J. V. Torres, Pilar Carbonero and F. García-Olmedo \\ Departamento de Bioquímica, Universidad Politécnica, E.T.S. Ingenieros, Agrónomos, Madrid-3. Spain
}

Key Word Index-Triticum aestivum; Gramineae; wheat; germination; phytosterols, sterol esters.

\begin{abstract}
Free and conjugated sterols of endosperm, coats, scutellum, coleoptile and roots have been analysed at different germination stages in two wheat cultivars with different endosperm sterol phenotypes. It seems that sterol metabolism of the developing tissues, namely coleoptile and roots, is not affected by the sterol conjugation profile of the endosperm. Enough sterol is present in the mature embryo to supply the germinating axis during the observation period $\left(144 \mathrm{hr}\right.$ at $16^{\circ}$. The data suggest that sterol is transferred from scutellum to coleoptile and roots during germination.
\end{abstract}

\section{INTRODUCTION}

We have previously described two genetic variants of the free and conjugated sterol profile in wheat endosperm [1-5]. One phenotype, designated PL, is characterized by a low proportion of free sterol and a high proportion of steryl palmitate, whereas in the other, $\mathbf{L}$. free sterol is the predominant form. This difference is controlled by allelic forms of a single gene, designated $P \ln$ [5]. Research reported here deals with the possible influence of endosperm sterol phenotype on sterol metabolism and development rate of the germinating axis.

\section{RESULTS}

The changes of total sterol in different structural parts of the wheat kernel during germination are represented in Fig. 1. There are no significant differences at this level between the two phenotypes.

The anatomical distributions of sterol forms at different stages of germination are summarized in Table 1 . The distribution patterns and their changes during germination are practically identical in homologous parts of PL and $L$ cultivars, with the exception of the endosperm.

Coleoptile and roots, which are actively growing, are characterized by a high proportion of free sterol that increases as germination proceeds. In contrast, the mature embryo has a total sterol level about 8 times higher than that of the growing tissues and most of it is in the esterified form. Oleate, linoleate and palmitate, in that order, are the main esters both in the whole mature embryo and in the scutellum at different stages of germination.

In scutellum and coats, which are being degraded, the relative depletion rate of all sterol forms is greater than that of non sterol dry matter.

Endosperm sterol is $82 \%$ esterified in the PL phenotype and $67 \%$ free in the L. Total and free sterol are both lost from the endosperm at a greater relative rate than non sterol matter in the two phenotypes. but the level of esterified sterol increases after $36 \mathrm{hr}$ of germination. However, data on the amounts per endosperm of each sterol form show that there is no net esterification (Fig. 2). In the $L$ phenotype, the amount per endosperm of each ester remains rather constant throughout germination, while the free sterol is extensively depleted. In the PL variety, steryl palmitate decreases sharply in the first $36 \mathrm{hr}$ and more slowly afterwards.

The distribution of the main 4-demethylsterols, sitosterol, stigmasterol, campesterol and cholesterol, in the different structural parts of the kernel is very similar in both varieties (Table 2 ).

The same sterols were also analysed in the various endosperm sterol forms at different stages of germination in order to ascertain if the sharp intervarietal difference in sterol conjugation profile affected each sterol (Table

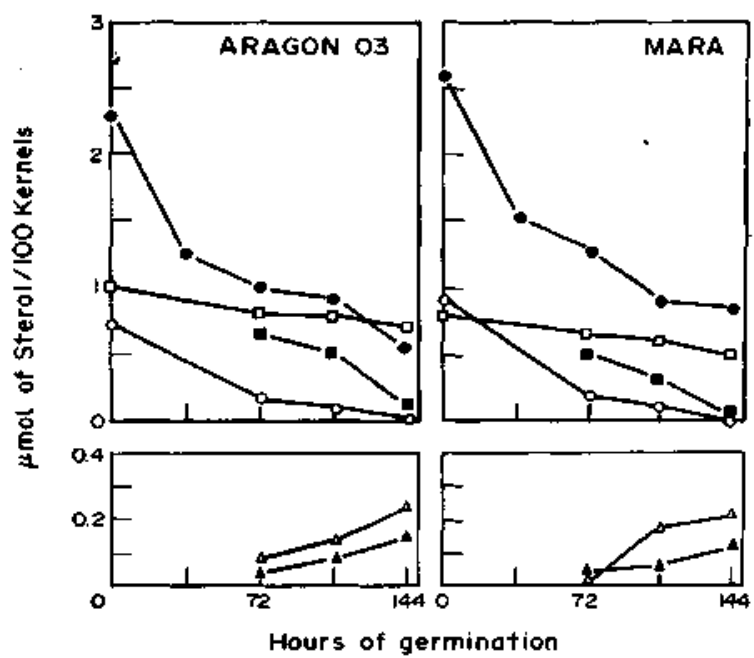

Fig. L. Total sterol in structural parts of T. aestitum ev. Aragon 03, PL phenotype, and cv Mara, L phenotype, at different germination stages. (๑) Endosperm; (D) embryo: (D) scutellum; $(O)$ coats; $(\Delta)$ coleoptile; $(\Delta)$ roots. 
Table 1. Changes of sterol forms in the structural parts of the wheat kernel in two cultivars with PL and L phenotypes during germination.

\begin{tabular}{|c|c|c|c|c|c|c|c|c|c|c|c|c|c|}
\hline \multirow{3}{*}{$\begin{array}{l}\text { Structural } \\
\text { part }\end{array}$} & \multirow{3}{*}{$\begin{array}{l}\text { Germination } \\
\text { time (hr) }\end{array}$} & \multicolumn{12}{|c|}{ Sterol form (micromol/100 g) } \\
\hline & & \multicolumn{2}{|c|}{ Free } & \multicolumn{2}{|c|}{ Palmitate } & \multicolumn{2}{|c|}{ Oleate } & \multicolumn{2}{|c|}{ Linoleate } & \multicolumn{2}{|c|}{ Glycoside } & \multicolumn{2}{|c|}{ Acyl glycoside } \\
\hline & & $\mathrm{A}^{*}$ & $\mathbf{M}^{*}$ & A & $M$ & A & M & A & M & A & $\mathbf{M}$ & A & $\mathbf{M}$ \\
\hline Embryo & 0 & 168,8 & 176,0 & 57,9 & 53,1 & 520,9 & 506,4 & 146,6 & 240,7 & 1.4 & 2.6 & 2.9 & 4,6 \\
\hline \multirow[t]{3}{*}{ Scutellum } & 72 & 190,5 & 174.8 & 36.7 & 36,9 & 133,4 & 120,8 & 100,1 & 74,0 & 1,8 & 1,9 & 4.8 & 4.1 \\
\hline & 108 & 177,3 & 159,2 & 31,6 & 28,2 & 106,3 & 102,2 & 74,0 & 45,8 & 1.1 & 1.5 & 3.4 & 3,4 \\
\hline & 144 & 139.1 & 132,4 & 24.5 & 23,1 & 104.2 & 96.0 & 39.3 & 43.6 & 0,9 & 1,2 & 2,9 & 2.6 \\
\hline \multirow[t]{3}{*}{ Roots } & 72 & $\mathbf{5 2 , 1}$ & 58,6 & 5,5 & 4,3 & 4,6 & 5,1 & 9,2 & 10,1 & 1.0 & 0.9 & 0,8 & 1.1 \\
\hline & 108 & 59,6 & 64,4 & 4,6 & 3,6 & 4,3 & 3,6 & 7,0 & 4.6 & 1,1 & 1.3 & 1.5 & 1,4 \\
\hline & 144 & 75,2 & 73,6 & 3,6 & 2,9 & 3,4 & 2,9 & 2.9 & 1.7 & 1.5 & 2,1 & 1.9 & 2.3 \\
\hline \multirow[t]{3}{*}{ Coleoptile } & 72 & 67,8 & 73,3 & 2,3 & 1,7 & 3,1 & 3,1 & 23,1 & 25.1 & 0.7 & 0.8 & 1.0 & 1,0 \\
\hline & 108 & 75,2 & 83.7 & 2,1 & 1,7 & 2,9 & 2,9 & 20,0 & 22,7 & 0,9 & 0,9 & 1.1 & 1,1 \\
\hline & 144 & 89.5 & 94,1 & 2.7 & 1,8 & 3.1 & 2,8 & 18,8 & 19.5 & 1,1 & 1.2 & 1,1 & 1,3 \\
\hline \multirow[t]{4}{*}{ Coats } & 0 & 107.1 & 108,1 & 11,6 & 12,5 & 9,9 & 10.6 & 14,2 & 18,8 & 0,5 & 0.5 & 1,2 & 1.4 \\
\hline & 72 & 35,9 & 28.7 & 5,5 & 5.8 & 3,8 & 4,6 & 5,8 & 6,3 & 0,4 & 0.5 & 0.6 & 0,9 \\
\hline & 108 & 24.1 & 20,7 & 5,3 & 5,3 & 3.4 & 4.1 & 5,6 & 5,5 & 0,3 & 0,4 & 0,5 & 0.8 \\
\hline & 144 & 16,1 & 11.8 & 4,6 & 4,8 & 3,4 & 4,3 & 6,0 & 4,3 & 0,2 & 0.2 & 0.3 & 0,4 \\
\hline \multirow[t]{5}{*}{ Endosperm } & 0 & 7.9 & 51,4 & 28,4 & 4.1 & 9.4 & 6,3 & 9,2 & 10.8 & 0.9 & 2,2 & 1.4 & 2.2 \\
\hline & 36 & 6.8 & 28,9 & 14,5 & 5.0 & 6.3 & 7.5 & 6.8 & 8.4 & 1,0 & 1.3 & 0.8 & 1.5 \\
\hline & 72 & 5.1 & 23,1 & 14,2 & 5,5 & 7,5 & 7.7 & 7.7 & 9.4 & 0.7 & 1,4 & 0.5 & 0.9 \\
\hline & 108 & 3,9 & 12,5 & 16.6 & 6.2 & 8,2 & 8.2 & 8,4 & 9.9 & 0,5 & 0.9 & 0.4 & 0.6 \\
\hline & 144 & 2,7 & 12,2 & 16,9 & 6.9 & 8,4 & 9.1 & 9.1 & 10,6 & 0.6 & 1.0 & 0,3 & 0,3 \\
\hline
\end{tabular}

*A. Aragon 03; PL, phenotype; M, Mara; L, phenotype.

3). No significant difference between sterols was found in either phenotype.

The possible relationship between endosperm sterol phenotype, mature kernel weight and $96 \mathrm{hr}$ germinated embryo weight was investigated. Results are summarized in Table 4. The significant difference in embryo weight between the two parents can be ascribed, at least in part, to the differences in kernel weight, which was found to be positively correlated with germinated embryo wejght

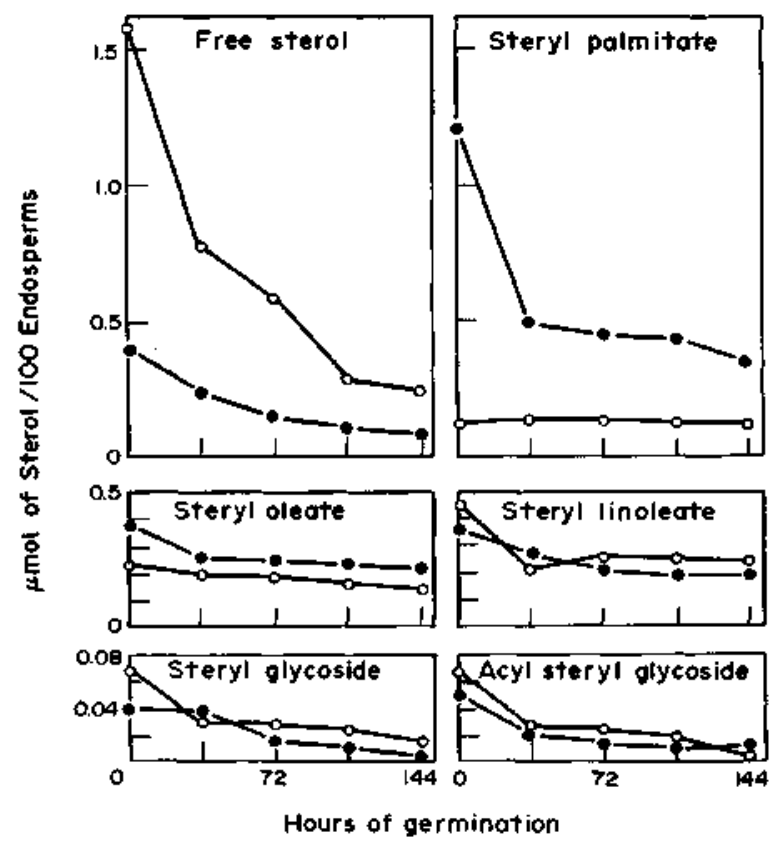

Fig. 2. Changes of sterol forms during germination in $T$. aesrivum cv Aragon 03, PL phenotype (๑), and cv. Mara, $L$ phenotype (O). $\left(r=0.619^{* * *}\right)$. No difference in kernel weight was found between $F_{2}$ kernels with PL and $\mathrm{L}$ phenolypes. Embryo weight of $F_{2}$ kernels with PL phenotype was lower than that of those with $L$ phenotype.

\section{DISCUSSION}

Kemp et al. [6] suggested that plant sterols might be transported as esters, by analogy with cholesterol transport in animal tissues. We speculated that if endosperm supplies sterol to tissues growing at its expense, and this sterol is transported in the ester form, differences in sterol metabolism of the developing coleoptile and roots could be associated with differences in the esterification ability of the endosperm. Our present results indicate that there is no influence of endosperm sterol phenotype on the sterols of the growing seedling.

The rate of disappearance of total sterol from the endosperm does not seem to be affected by the difference in the degree of sterol esterification that exists between the two phenotypes. In the PL phenotype, sterol esters disappear faster than non-sterol matter in the first $72 \mathrm{hr}$ of germination and then slower, while in the $\mathbf{L}$ phenotype, the rate is slower throughout the germination period. Other non-polar acyl lipids from wheat endosperm are catabolized faster than non-fat matter [7].

The somewhat smaller germinated embryo weight associated with the PL phenotype in the $F_{2}$ generation may be the effect of gene $P / n$ or of a genetically linked factor. If the first alternative is in fact operating. it seems more likely that the effect would be an indirect one. such as a difference in the rate of nutrient supply by the endosperm, and not a specific effect on sterol metabolism of the growing seedling. In any case, the results indicate that gene(s) affecting seedling development rate are located in the same chromosome as gene $P h$. which has been previously assigned to the short arm of chromosome 7D [3]. 
Table 2. Distribution of 4-demethylsterols in structural parts of mature and germinated wheat kernels with PL and L phenotypes

\begin{tabular}{|c|c|c|c|c|c|c|c|c|c|}
\hline \multirow{3}{*}{$\begin{array}{c}\text { Structural } \\
\text { part }\end{array}$} & \multirow{3}{*}{$\begin{array}{l}\text { Germination } \\
\text { time }(\mathrm{hr})\end{array}$} & \multicolumn{8}{|c|}{ Sterol class $(\%)$} \\
\hline & & \multicolumn{2}{|c|}{ Sitosterol } & \multicolumn{2}{|c|}{ Stigmasterol } & \multicolumn{2}{|c|}{ Campesterol } & \multicolumn{2}{|c|}{ Cholesterol } \\
\hline & & $A^{*}$ & $\mathbf{M}^{*}$ & A & $\mathbf{M}$ & A & M & A & $\mathbf{M}$ \\
\hline Embryo & 0 & 63,3 & 55,2 & 9.4 & 16.2 & 16.1 & 12,8 & 11.2 & 15.8 \\
\hline Scutellum & 144 & 81,9 & 69.6 & 2,3 & 10,4 & 14.5 & 17,4 & 1,3 & 2,6 \\
\hline Coleoptile & 144 & 87,2 & 88,2 & 1,3 & 0,4 & 7.1 & 10,0 & 4.4 & 1,4 \\
\hline Roots & 144 & 84,8 & 85.6 & 2,9 & 2.0 & 9.6 & 10.2 & 2.7 & 2.2 \\
\hline \multirow[t]{2}{*}{ Coats } & 0 & 67,2 & 65,3 & 10,6 & 10.2 & 10.6 & 10,9 & 11.6 & 13.6 \\
\hline & 144 & 83.4 & 80.9 & 3,5 & 6.4 & 11,1 & 6.0 & 2,0 & 6.7 \\
\hline \multirow[t]{2}{*}{ Endosperm } & 0 & 67,0 & 75.0 & 14,6 & 13,6 & 4.6 & 3.8 & 13.3 & 7.6 \\
\hline & 144 & 66,0 & 64.4 & 7,7 & 7,4 & 11.1 & 12.0 & 15.2 & 16,2 \\
\hline
\end{tabular}

*A. Aragon 03: PL, phenotype: M. Mara: L. phenotype.

Changes in the distribution of sterol forms during germination have been reported for a number of plant species [6,8-12]. The intraspecific differences reported here are more drastic than most of those reported between different species.

Data in Fig. 1 indicate that there are enough sterols in the mature embryo to supply the developing seedling during the period studied. The rapid decline of scutellum sterols is concomitant with, and of the same order as, their increase in coleoptile and roots. Most of the mature embryo sterols are esterified and we have previously shown that about $2 / 3$ of these esters are synthesized just prior to maturity, when seeds are starting to dry [5]. These facts suggest a storage role for the embryo sterol esters. The low glycoside content excludes them as storage forms in this case.

In $72 \mathrm{hr}$ scutellum, the total sterol level (dry matter basis) is about half that of mature embryo and 6-8 times higher than that of the developing tissues at the same stage. Furthermore, the proportion of esterified sterol in scutellum $(40-42 \%)$ is also intermediate between that of the embryo $(80-82 \%)$ and that of the coleoptile and roots $(26-29 \%)$. These observations suggest that a redistribu- tion of embryo sterols is taking place during germination.

Adler and Kasprzyk [13] found that the incorporation of mevalonate-[2-14C], absorbed by seedlings of Calendula officinalis, into sterols was rather slow. Earlier, Duperon [11] had reported very low incorporation of mevalonate- $\left[2-{ }^{14} \mathrm{C}\right]$ into sterols, with good incorporation into triterpenes, in Phaseolus vulgaris and Raphanus satious. In all cases, there was less incorporation into the ester fraction. These results would also be consistent with the redistribution hypothesis.

Our present and previous results [4.5] suggest that endosperm is not involved in supplying sterols to the growing tissues during germination and that, on the other hand, enough sterols are accumulated as esters in the embryo during development to serve that purpose.

\section{EXPERIMENTAL}

Plant material. Triticum aestitum L. cultivars, Aragon 03 (PL phenotype) and Mara (L), and an $F_{2}$ generation from a cross between these cultivars were used in our studies. Kernels from the two cultivars were germinated in the dark at

Table 3. Distribution of 4-demethylsterols in endosperm sterol forms in cultivars with PL and L phenotypes at different stages of germination

\begin{tabular}{|c|c|c|c|c|c|c|c|c|c|}
\hline \multirow[b]{3}{*}{ Sterol form } & \multirow{3}{*}{$\begin{array}{c}\text { Germination } \\
\text { time (hr) }\end{array}$} & \multicolumn{8}{|c|}{ Sterol class (micromol/1000 endosperms) } \\
\hline & & \multicolumn{2}{|c|}{ Sitosterol } & \multicolumn{2}{|c|}{ Stigmasterol } & \multicolumn{2}{|c|}{ Campesterol } & \multicolumn{2}{|c|}{ Cholesterol } \\
\hline & & $A^{*}$ & $\mathbf{M}^{*}$ & A & $\mathbf{M}$ & A & $\mathbf{M}$ & A & M \\
\hline \multirow[t]{2}{*}{ Free } & 0 & 33,1 & 137,1 & 5,0 & 11,9 & 1,2 & 5,5 & 0,9 & 0.9 \\
\hline & 144 & 7.8 & 7.5 & 1.1 & 1,2 & 0.4 & 0.5 & 0.7 & 0.9 \\
\hline \multirow[t]{2}{*}{ Palmitate } & 0 & 75,4 & 10,9 & 26,9 & 0,6 & 5.1 & 0,8 & 13.5 & 0.7 \\
\hline & 144 & 17,9 & 5,9 & 3,1 & 1.6 & 2,5 & 2,3 & 3,5 & 0.2 \\
\hline \multirow[t]{2}{*}{ Oieate } & $\mathbf{0}$ & 30.9 & 16.6 & 5.1 & 1.1 & 0.8 & 1,0 & 1.7 & 1.4 \\
\hline & 144 & 8,5 & 7,8 & 0,1 & 0.2 & 2,1 & 1,9 & 3,0 & 3,1 \\
\hline \multirow[t]{2}{*}{ Linoleate } & 0 & 30.5 & 36.0 & 4.8 & 7,2 & 1,6 & 1,7 & 1.7 & 2,2 \\
\hline & 144 & 7,7 & 7,4 & 0,9 & 0,6 & 1,8 & 1.5 & 2,6 & 4,1 \\
\hline \multirow[t]{2}{*}{ Glycoside } & 0 & 3,9 & 5,8 & 0,1 & 0.3 & 0,5 & 0,4 & 0.3 & 0,3 \\
\hline & 144 & 1.8 & 0.3 & 0.1 & $0, \mathrm{~L}$ & 0.2 & 0.1 & $0 . \underline{2}$ & 0.2 \\
\hline \multirow[t]{2}{*}{ Acyl-glycoside } & o & 4,7 & 5,7 & 0,2 & 0.1 & 0,3 & 0,5 & 0,3 & 0,4 \\
\hline & 144 & 3,2 & 6,1 & 0,2 & 0.3 & 0,9 & 0.2 & 0.8 & 0,3 \\
\hline \multirow[t]{2}{*}{ Total } & o & 178,5 & 212,7 & 44,8 & 21,2 & 9,5 & 9.9 & 18,4 & 5.9 \\
\hline & 144 & 46.9 & 35.0 & 5.5 & 4,0 & 7,9 & 6.5 & 10,8 & 8,8 \\
\hline
\end{tabular}

* A, Aragon 03; PL, phenotype; M, Mara; L. phenotype. 
Table 4. Weights of mature kernels and $96 \mathrm{hr}$ germinated embryos of an $F_{2}$ generation from a cross Aragon 03 $(\mathrm{PL}) \times$ Mara $(\mathrm{L})^{*}$

\begin{tabular}{|c|c|c|c|}
\hline Stock & $\begin{array}{l}\text { Sample } \\
\text { size }\end{array}$ & $\begin{array}{c}\text { Mean kernel } \\
\text { wt (mg) }\end{array}$ & $\begin{array}{c}\text { Mean embryo } \\
\text { wt (mg) }\end{array}$ \\
\hline $\begin{array}{l}\text { Aragon } 03(\mathrm{PL}) \\
\text { Mara (L) } \\
\mathbf{F}_{2}(\mathrm{PL}) \\
\mathbf{F}_{2}(\mathrm{~L})\end{array}$ & $\begin{array}{l}100 \\
100 \\
464 \\
145\end{array}$ & $\begin{array}{l}45,9^{a} \dagger \\
39,7^{\mathrm{b}} \\
42,9^{\mathrm{c}} \\
42,8^{\mathrm{c}}\end{array}$ & $\begin{array}{l}3,24^{\mathrm{a}} \\
2,39^{\mathrm{b}} \\
2,27^{\mathrm{c}} \\
2,38^{\mathrm{b}}\end{array}$ \\
\hline
\end{tabular}

* Kernels with $\mathrm{PL}$ and $\mathrm{L}$ phenotypes were identified in the $F_{2}$ after $96 \mathrm{~h}$ germination. † Means within a column followed by the same letter are not significantly different at the 0.05 level.

$16^{\circ}$ and close $10100 \%$ mojsture. Samples $(40 \mathrm{~g})$ were steeped in a $5 \%$ calcium hypochlorite soln for $2 \mathrm{hr}$, then washed repeatedly with sterile $\mathrm{H}_{2} \mathrm{O}$, and finally steeped in sterile $\mathrm{H}_{2} \mathrm{O}$ for $24 \mathrm{hr}$. Germination was carried out between sterile moist filter paper. Samples were taken each $36 \mathrm{hr}$ and freeze-dried. The dry, germinated kernels, were dissected by hand into endosperm, coats (pericarp, seed coat and some aleurone), scutellum, roots, and coleoptile. To study the possible relationship between mature kernel wi, seedling development and endosperm sterol phenotype, 100 kernels from each parental and 609 kernels from the $F_{2}$ generation were individually weighed and simultaneously germinated in the same tray. After $96 \mathrm{hr}$ of germination, the whole tray was placed at $-20^{\circ}$. Embryos and the rest of the kernels were separated while frozen, placed in separate tubes and dried for $2 \mathrm{hr}$ at $90^{\circ}$. Dried embryos were weighed and the rest of the kernels were used to deter- mine sterol phenotype as previously described [3]. Conventional statistical methods were applied..

Analytical procedures. The anajytical procedures used were described previously [3,5].

Acknowledgements--We thank L. Torres and J. Diaz-L]anos for carrying out the statistical calculations.

\section{REFERENCES}

1. Garcia-Faure, R., Garcia-Olmedo, F. and Vallejo, J. M. (1968) J. Sci. Food Agr. 19. 322.

2. Garcia-Olmedo. F. (1968) Nature 220, 1144

3. Torres, J. V. and Garcia-Olmedo. F. (1974) Plant Sci. Letters 3, 213.

4. Carbonero, P.. Torres, J. V. and Garcia-Olmedo (1975) FEBS Letters 56. 198.

5. Torres, J. V. and García-Olmedo, F. (1975) Biochim. Biophys. Acta 409, 367.

6. Kemp, R. J., Goad, L. J. and Mercer, E. I. (1967) Phytochemistry 6, 1609 .

7. García-Olmedo, F. and Glass, R. L. (1969) Anoles INIA Madrid 18. 299.

8. Duperon, P. (1968) C.R. Acad. Sci. Paris 266. 1658.

9. Kasprzyk, Z.. Pyrek, J., Turowska, G. (1968) Acta Biochim. Polon. 15, 149.

10. Duperon, P, and Duperon, R. (1969) C.R. Acad. Sci. Paris 269. 157.

11. Duperon, P. (1971) Physiol. Vég. 9. 373.

12. Bush, P. B. and Grunwald, C. (1972) Plant Physiol. 50. 69.

13. Adler, G. and Kasprzyk, Z. (1975) Phytochemistry 14. 723. 